\title{
Hill placement of manure and fertilizer micro-dosing improves yield and water use efficiency in the Sahelian low input millet-based cropping system
}

\author{
Ali Ibrahim ${ }^{\mathrm{a}, \mathrm{b}, *}$, Robert Clement Abaidoo ${ }^{\mathrm{a}, \mathrm{c}}$, Dougbedji Fatondji ${ }^{\mathrm{b}}$, Andrews Opoku ${ }^{\mathrm{a}}$ \\ a Department of Crop and Soil Sciences, Kwame Nkrumah Univeristy of Science and Technology, Kumasi, South Ghana \\ ${ }^{\mathrm{b}}$ International Crops Research Institute for the Semi-Arid Tropics (ICRISAT), BP 12404, Niamey, Niger \\ ' International Institute of Tropical Agriculture, PMB 5320, Ibadan, Nigeria
}

\section{A R T I C L E I N F O}

\section{Article history:}

Received 18 February 2015

Received in revised form 28 April 2015

Accepted 29 April 2015

\section{Keywords:}

Millet

Fertilizer micro-dosing

Manure

Hill-placement

Yield

Water use efficiency

\begin{abstract}
A B S T R A C T
Inadequate nutrient supply and insufficient rainfall are the most important limiting factors for crop production in the Sahelian agro-ecological zones. Targeted technology application may help to improve the efficient use of limited nutrient and water resources. The objective of this study was to determine the optimal combination of fertilizer micro-dosing and manure application rates for improved millet yield and enhanced water use efficiency in low input millet-based cropping system. A two-year field experiment was conducted at a research station in Niger using a randomized complete block design with three replications. The treatments consisted of the factorial combination of: (i) two fertilizer microdosing options ( $20 \mathrm{~kg} \mathrm{ha}^{-1}$ of diammonium phosphate (DAP) and $60 \mathrm{~kg} \mathrm{ha}^{-1}$ of NPK corresponding to $2 \mathrm{~g}$ hill ${ }^{-1}$ of DAP and $6 \mathrm{~g}$ hill $^{-1}$ of NPK, respectively), (ii) cattle manure at four application rates $\left(0 \mathrm{~kg} \mathrm{ha}^{-1}\right.$, $1000 \mathrm{~kg} \mathrm{ha}^{-1}, 2000 \mathrm{~kg} \mathrm{ha}^{-1}, 3000 \mathrm{~kg} \mathrm{ha}^{-1}$ ) and (iii) two methods of manure application (broadcasting and hill placement). Millet grain yields under fertilizer micro-dosing combined with manure was increased on average by $59 \%, 83 \%$ and $113 \%$ for $1000 \mathrm{~kg} \mathrm{ha}^{-1}, 2000 \mathrm{~kg} \mathrm{ha}^{-1}$ and $3000 \mathrm{~kg} \mathrm{ha}^{-1}$, respectively compared with fertilizer micro-dosing alone. Combined applications of manure and fertilizer micro-dosing increased water use efficiency significantly. Hill placement of manure increased total dry matter on average by $23 \%$ and water use efficiency by $35 \%$ relative to manure broadcasting. The total root length density was increased by $66 \%$ and $42 \%$ in hill placement of manure at $25 \mathrm{~cm}$ and $50 \mathrm{~cm}$, respectively, from the hill centre compared with manure broadcast. These results indicate that millet production with the fertilizer micro-dosing technology can be improved further by hill-placement of manure. The combination of $2000 \mathrm{~kg} \mathrm{ha}^{-1}$ of manure and $20 \mathrm{~kg} \mathrm{DAP} \mathrm{ha}^{-1}$ hill-placed were most promising for increasing millet yield and the efficient use of limited nutrients and water in Sahelian millet based systems. There is need for testing this technology further together with farmers to valuate its effectiveness.
\end{abstract}

(c) 2015 Elsevier B.V. All rights reserved.

\section{Introduction}

Pearl millet is the major food cereal cultivated in the Sahelian agro-ecological of Niger on coarser textured soils using up to $90 \%$ of the cropped area (Bationo et al., 1993). Even though this crop has a potential to adapt to harsh conditions, particularly low soil fertility, its yield is often very low with an average of $400 \mathrm{~kg} \mathrm{ha}^{-1}$ in low input smallholder millet farming systems (Sivakumar and Salaam,

\footnotetext{
* Corresponding author at: International Crops Research Institute for the SemiArid Tropics (ICRISAT) BP: 12404, Niamey, Niger.

Tel.: +227 962673 74; +233 267085456; fax: +22720734329.

E-mail addresses: ibramali@myway.com, ibabaye@gmail.com (A. Ibrahim).
}

1999). The inherent low soil fertility coupled together with inappropriate soil fertility management and unreliable rainfall are main causes underlying the low millet productivity in the Sahelian zone of Niger (Graef and Haigis, 2001; Schlecht et al., 2006; Stoorvogel and Smaling, 1990).

The use of mineral fertilizers by farmers in Niger remains very low and unattractive because of their high cost (Abdoulaye and Sanders, 2005; Bationo et al., 2003). To improve the efficient use and to encourage smallholder farmers to increase the on-farm application of mineral fertilizer, the fertilizer micro-dosing technology developed by ICRISAT and partners has shown promising results in improving millet yields in the Sahel (Aune and Bationo, 2008; Tabo et al., 2007). This technology consists of the application of a small quantity of mineral fertilizer (one third of the recommended rate) 
to the target crop seeds on the planting hill at the sowing event or few weeks after planting (Hayashi et al., 2008; ICRISAT, 2009). However, in recent works on millet response to fertilizer micro-dosing technology, it was indicated that low soil organic matter characterizing the Sahelian sandy soils contributes immensely to the low millet yield response to this technology (Manyame, 2006; Tabo et al., 2011). Therefore, it appears that to enhance crop response to fertilizer micro-dosing technology, there is a need to supplement it with an organic resource.

The effectiveness of integrated use of mineral and organic amendment in improving crop yields and maintaining (sustainably) soil fertility has been well documented (Akponikpé et al., 2008; Bationo et al., 2003; Yamoah et al., 2002), but the availability of the resources for achieving these positive effects remains a major challenge, especially in the Sahelian countries. The main sources of organic amendments such as crop residue are used for other purposes and thereby limit their availability for use as soil amendment (Bationo et al., 1995; Buerkert and Hiernaux, 1998). Animal manure is the most common organic resource for smallholder farmers but its availability in sufficient quantity is also a major challenge (De Ridder and Van Keulen, 1990; McIntire et al., 1993). One of the available options for addressing this problem could be through hill placement of manure which could be a strategy for increasing millet productivity when combined with fertilizer micro-dosing. The objective of the current study was therefore to determine the optimal combination of fertilizer micro-dosing and manure applications for achieving high millet yields, nutrient and water use efficiencies in low input millet-based cropping system.

\section{Materials and methods}

\subsection{Description of experimental site}

The experiment was carried out at the International Crops Research Institute for the Semi-Arid Tropics (ICRISAT) research station, Sadoré, Niger $\left(13^{\circ} 15^{\prime} \mathrm{N}\right.$ and $2^{\circ} 18^{\prime} \mathrm{E}, 240 \mathrm{~m}$ above sea level). The climate is typical of the southern edge of the Sahelian zone, with summer rainfall and high temperature throughout the year (Sivakumar et al., 1993). The mean annual rainfall (1983-2013) at the research station of Sadoré is $551 \pm 110 \mathrm{~mm}$ ( \pm standard deviation) and the average temperature is $29^{\circ} \mathrm{C}$ (ICRISAT climate database). The experimental field had a sandy soil with low organic carbon content $(0.20 \%$ in the upper $40 \mathrm{~cm}$ of soil) which limits nutrients storage and water holding ability. The total nitrogen $(\mathrm{N})$ content and extractable phosphorus (P-Bray) contents were also low with $205 \mathrm{mg} \mathrm{kg}^{-1}$ and $7.9 \mathrm{mg} \mathrm{kg}^{-1}$, respectively, soil $\mathrm{pH}\left(\mathrm{H}_{2} \mathrm{O}\right)$ was about 5 (Table 1 ).

\subsection{Experimental set up}

The experiment was conducted during the rainy season in 2013 and 2014 in a randomized complete block design with three replications. The treatments consisted of factorial combinations of: (i) two fertilizer micro-dosing options: $20 \mathrm{~kg} \mathrm{ha}^{-1}$ of diammonium phosphate (DAP) (equivalent to $4 \mathrm{~kg} \mathrm{Pha}^{-1}$ and $3.6 \mathrm{~kg} \mathrm{~N} \mathrm{ha}^{-1}$ ) and $60 \mathrm{~kg} \mathrm{ha}^{-1}$ of composite fertilizer NPK 15-15-15(equivalent to $4 \mathrm{~kg}$ $\mathrm{P}$ ha ${ }^{-1}, 9 \mathrm{~kg} \mathrm{Nha}^{-1}$ and $7.47 \mathrm{~kg} \mathrm{Kha}^{-1}$ ). The micro-dosing rates correspond to $2 \mathrm{~g}$ DAP hill ${ }^{-1}$ and $6 \mathrm{~g}$ NPK hill ${ }^{-1}$, respectively. (ii) Cattle manure with four application rates $\left(0 \mathrm{~kg} \mathrm{ha}^{-1}, 1000 \mathrm{~kg} \mathrm{ha}^{-1}\right.$, $2000 \mathrm{~kg} \mathrm{ha}^{-1}, 3000 \mathrm{~kg} \mathrm{ha}^{-1}$ ) and (iii) two methods of manure application (broadcasting and hill placement). Individual $5 \mathrm{~m} \times 6 \mathrm{~m}$ plots were separated by a $1 \mathrm{~m}$ alley. The space between the planting hills was $1 \mathrm{~m} \times 1 \mathrm{~m}$ to achieve a density of 10,000 hills ha $^{-1}$ as recommended in Niger. In the plots receiving broadcasted manure, $3 \mathrm{~kg} \mathrm{plot}^{-1}, 6 \mathrm{~kg} \mathrm{plot}^{-1}$ and $9 \mathrm{~kg} \mathrm{plot}^{-1}$ corresponding to $^{-1}$
Table 1

Initial soil chemical and physical properties of the experimental field.

\begin{tabular}{|c|c|c|c|}
\hline Parameters & $0-10 \mathrm{~cm}$ & $10-20 \mathrm{~cm}$ & $20-40 \mathrm{~cm}$ \\
\hline \multicolumn{4}{|l|}{ Soil texture } \\
\hline Sand (\%) & 94.1 & 95.0 & 92.1 \\
\hline Silt (\%) & 3.9 & 2.2 & 2.1 \\
\hline Clay (\%) & 2.0 & 2.8 & 5.4 \\
\hline \multicolumn{4}{|l|}{ Soil chemical properties } \\
\hline $\mathrm{pH}-\mathrm{H}_{2} \mathrm{O}$ & 5.1 & 4.9 & 4.7 \\
\hline $\mathrm{pH}-\mathrm{KCl}$ & 4.8 & 4.1 & 3.9 \\
\hline Organic C (\%) & 0.31 & 0.15 & 0.13 \\
\hline Total N(mg kg-1 $)$ & 311.1 & 170.3 & 134.8 \\
\hline Extractable $\mathrm{P}\left(\mathrm{mg} \mathrm{kg}^{-1}\right)$ & 8.9 & 7.7 & 7.2 \\
\hline Ammonium( $\left.\mathrm{mg} \mathrm{kg}^{-1}\right)$ & 8.8 & 5.5 & 3.7 \\
\hline Nitrate $\left(\mathrm{mg} \mathrm{kg}^{-1}\right)$ & 19.3 & 11.7 & 5.9 \\
\hline $\mathrm{Na}^{+}\left(\mathrm{cmol} \mathrm{kg}^{-1}\right)$ & 0.01 & 0.01 & 0.01 \\
\hline $\mathrm{K}^{+}\left(\mathrm{cmol} \mathrm{kg}^{-1}\right)$ & 0.17 & 0.16 & 0.17 \\
\hline $\mathrm{Ca}^{2+}\left(\mathrm{cmol} \mathrm{kg}^{-1}\right)$ & 1.0 & 1.3 & 0.8 \\
\hline $\mathrm{Mg}^{2+}\left(\mathrm{cmol} \mathrm{kg}^{-1}\right)$ & 0.4 & 0.6 & 0.3 \\
\hline $\mathrm{H}^{+}(\mathrm{meq} / 100 \mathrm{~g})$ & 0.1 & 0.1 & 0.2 \\
\hline $\mathrm{Al}^{3+}(\mathrm{meq} / 100 \mathrm{~g})$ & 0.0 & 0.2 & 0.3 \\
\hline
\end{tabular}

$\mathrm{H}_{2} \mathrm{O}$, water; OC, organic carbon; $\mathrm{N}$, nitrogen; $\mathrm{P}$, phosphorus.

$1000 \mathrm{~kg} \mathrm{ha}^{-1}, 2000 \mathrm{kgha}^{-1}$ and $3000 \mathrm{~kg} \mathrm{ha}^{-1}$, respectively were broadcast over the plots and superficially incorporated into the soil with a long hand-led hoe known as a "hiliaire". For manure hill placement, small planting hills of $15 \mathrm{~cm}$ diameter and $15 \mathrm{~cm}$ depth each were dug in the experimental plots and $100 \mathrm{~g} \mathrm{hill}^{-1}$, $200 \mathrm{~g} \mathrm{hill}^{-1}$ and $300 \mathrm{ghill}^{-1}$ were applied, which represented $1000 \mathrm{~kg} \mathrm{ha}^{-1}, 2000 \mathrm{~kg} \mathrm{ha}^{-1}$ and $3000 \mathrm{~kg} \mathrm{ha}^{-1}$ respectively. Seeds of improved pearl millet variety ICMV-IS 89305 (110 maturity days) were sown according to the onset of the rainy season on 10 July, 2013 and 1st June, 2014. The millet was thinned to three plants per hill at three weeks after planting. There were three weeding events during the growing period. The harvest periods occurred on 10 October in 2013 and 15 September in 2014. To determine grain yield and dry matter yield, samples of straw and manuallythreshed millet panicles were harvested from the central $4 \mathrm{~m} \times 5 \mathrm{~m}$ of each plot and sun-dried at $65^{\circ} \mathrm{C}$ for $48 \mathrm{~h}$, weighed and expressed in $\mathrm{kg} \mathrm{ha}^{-1}$.

\subsection{Soil sampling and analysis}

Composite soil samples were taken prior to the land preparation at depths of $0-10 \mathrm{~cm}, 10-20 \mathrm{~cm}$ and $20-40 \mathrm{~cm}$. Each sample was analyzed for $\mathrm{pH}_{\mathrm{H} 2 \mathrm{O}}$ (soil/water ratio of $1: 2.5$ ), Organic carbon was determined with the method described by Walkley and Black (1934), total N by Kjeldahl method (Houba et al., 1995) and extractable phosphorus by the Bray 1 method (van Reeuwijk, 1993).

\subsection{Root sampling and root length determination}

In 2013, two millet hills from each treatment were sampled and roots were collected at tillering and dough stages with a metal frame measuring $15 \times 10 \times 10 \mathrm{~cm}^{3}$ from 0 to $20 \mathrm{~cm}$ directly under the hill. Below this depth, roots were collected at $20 \mathrm{~cm}$ depth increment with an aluminium tube of $7.5 \mathrm{~cm}$ in diameter. The roots were washed, debris and dead roots removed. The root length was calculated by determining root intersections $(\mathrm{N})$ using the grid counting method (Tennant, 1975). The grid size of $2 \mathrm{~cm} \times 2 \mathrm{~cm}^{2}$ was used for the coarse roots and the grid of $1 \mathrm{~cm} \times 1 \mathrm{~cm}$, for the fine roots. The coarse roots were counted on a sub-sample of $2 \mathrm{~g}$ taken from the main root sample. In the case of the fine roots, if the fresh weight of the total sample was more than $1 \mathrm{~g}$, a sub-sample of $1 \mathrm{~g}$ was taken for the count. The samples were cut into small pieces of $1 \mathrm{~cm}$ and 
spread in the dish with a small amount of water. Root length was calculated using the following formula:

$R=\frac{N \times \text { total root fresh weight }}{\text { Root weight of sub-sample }}$

where, $N=$ number of intersections counted. Root length density (RLD) was determined by the following formula: $R L D=R / V$, where, $R$ is Root length and $V$ is soil volume of corresponding depth.

In 2014, the roots were sampled in three positions, directly under the hill and at two lateral distances $(25 \mathrm{~cm}$ and $50 \mathrm{~cm})$ relative to the hill in four directions. After washing and removing dead roots and debris, all the roots samples collected were scanned through a scanner with $200 \mathrm{dpi}$ resolution. Root images were analysed using WinRhizo Pro software (Regent Instruments Canada Inc.) to calculate root length; and then root length density (RLD) was calculated from the root length and the soil core volume.

\subsection{Soil moisture monitoring}

Rainfall data was recorded with a rain gauge located at the experimental field. Access tubes were installed in all the plots to monitor weekly soil moisture with a calibrated neutron probe from 0.15 to $2 \mathrm{~m}$ depth at $0.15 \mathrm{~m}$ intervals. The change in soil water storage in the root zone was calculated from the equation used by Payne (1997) as follows:

$\mathrm{dS}=\mathrm{R}-(\mathrm{ET}+\mathrm{D})$

where, $\mathrm{dS}$, is the change in soil water storage in the root zone, $\mathrm{R}$ is rainfall, ET is evapo-transpiration and D is the root zone drainage. Drainage and ET were determined from the weekly neutron-probe data using the method developed by Klaij and Vachaud (1992). This method divides the water balance into two phases. In the first phase, applicable early in the season, water flux across the maximum depth of probe measurement $(\mathrm{Zm})$ is assumed negligible. Drainage (D) was calculated from the change in soil water content $(\theta)$ between the bottom of the root zone $(\mathrm{Zr})$ and $\mathrm{Zm}$, thus allowing calculation of unsaturated hydraulic conductivity, $K(\theta)$, from the flux across $\mathrm{Zr}$. In the second phase, when soil water starts to percolate across $\mathrm{Zm}$, D is calculated from $K(\theta)$, assuming a hydraulic head gradient of -1 . The details of this method were given by Klaij and Vachaud (1992).

Water use efficiency $\left(\mathrm{kg} \mathrm{mm}^{-1}\right)$ was calculated as a ratio of grain yield to evapo-transpiration (Wang et al., 2010).

\subsection{Statistical analysis}

Prior to the analysis, data were carefully checked for normal distribution in GENSTAT v.9 using distributions options. Square root (Sqrt) transformation was applied to root length density data only to ensure normal distribution because the data failed to satisfy this assumption of analysis of variance. The analysis of variance was therefore performed with GENSTAT v.9 (Lawes Agricultural Trust, 2007) using a General Treatment Structure (in Randomized Blocks). Differences between treatments were considered at error probabilities $\leq 0.05$.

\section{Results}

\subsection{Rainfall distribution during the cropping period}

Fig. 1 shows the total rainfall recorded during the cropping period in 2013 and 2014. The total rainfall recorded was $475 \mathrm{~mm}$ and $689 \mathrm{~mm}$ in 2013 and 2014, respectively. In 2013, the rainfall was about $76 \mathrm{~mm}$ less than the long-term rainfall $(551 \mathrm{~mm})$ recorded at the experimental site (ICRISAT Climate Service) and

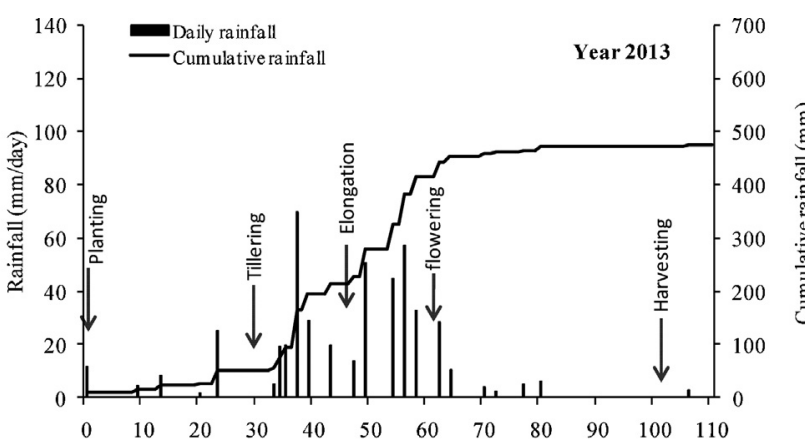

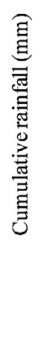

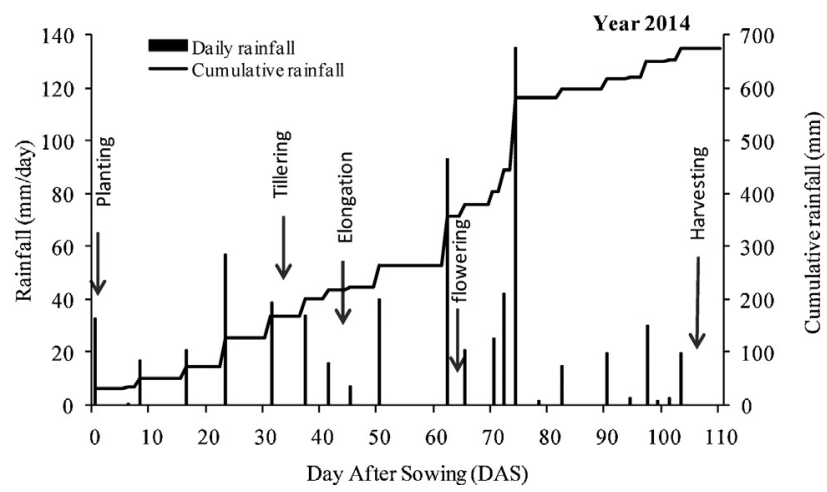

Fig. 1. Rainfall distribution during the cropping period.

it was mostly concentrated between 20 to 68 days after sowing (DAS), corresponding to the flowering stage. A long dry spell of 25 days occurred coinciding with millet reproductive stage period. The rainfall was more evenly distributed in 2014 compared with 2013.

\subsection{Effect of treatments on grain and total dry matter yields}

Grain yield and total dry matter yield as affected by the treatments are shown in Table 2 and the summary of analysis of variance is presented in Table 3 . The grain yields were significantly $(P<0.001)$ affected by the planting seasons; the highest grain yields were recorded in 2014 compared to 2013. There was a significant difference $(P<0.001)$ in grain yield between fertilizer micro-dosing options; the grain yield recorded with $2 \mathrm{~g}$ DAP hill ${ }^{-1}$ was significantly higher than that of $6 \mathrm{~g} \mathrm{NPK}$ hill $^{-1}$ treatments. Similarly, the total dry matter (TDM) production was highest with $2 \mathrm{~g}$ DAP hill ${ }^{-1}$ compared with the $6 \mathrm{~g}$ NPK hill ${ }^{-1}$ treatments. The grain yields were much lower in the fertilizer micro-dosing treatment plots compared to those receiving the combined application of fertilizer micro-dosing and manure. There was a marked increase in millet grain yield when manure was added to fertilizer microdosing treatments $\left(2 \mathrm{~g} \mathrm{DAPhill}{ }^{-1}\right.$ and $6 \mathrm{~g} \mathrm{NPK} \mathrm{hill}{ }^{-1}$ ) regardless of the mode of manure application. Adding manure to fertilizer micro-dose increased millet grain yields on average by $59 \%, 83 \%$ and $113 \%$, respectively for $1000 \mathrm{~kg} \mathrm{ha}^{-1}, 2000 \mathrm{~kg} \mathrm{ha}^{-1}$ and $3000 \mathrm{~kg} \mathrm{ha}^{-1}$ application rates. The hill placement of manure performed better in improving millet grain yield irrespective of the fertilizer micro-dosing options. However, there was no significant interaction between fertilizer micro-dosing options and the mode of manure placement in grain millet yield.

The TDM increased significantly with increasing level of manure regardless to the fertilizer micro-dosing treatments. The highest TDM was recorded with hill placement of manure compared to broadcasting of the same rate of manure. Hill placement of manure significantly increased TDM production on average by 23\% in 2013 and $22 \%$ in 2014 as compared to manure broadcasting. 
Table 2

Effect of the treatments on the grain yield and total dry matter.

\begin{tabular}{|c|c|c|c|c|c|}
\hline \multirow[t]{2}{*}{ Fertilizer micro-dosing option } & \multirow[t]{2}{*}{ Manure rate $\left(\mathrm{kg} \mathrm{ha}^{-1}\right)$} & \multicolumn{2}{|c|}{ Grain yield $\left(\mathrm{kg} \mathrm{ha}^{-1}\right)$} & \multicolumn{2}{|c|}{ Total dry matter $\left(\mathrm{kg} \mathrm{ha}^{-1}\right)$} \\
\hline & & 2013 & 2014 & 2013 & 2014 \\
\hline \multirow[t]{4}{*}{$2 \mathrm{~g} \mathrm{DAPhill}^{-1}$} & 0 & $354 \pm 57$ & $876 \pm 24$ & $1642 \pm 135$ & $3963 \pm 171$ \\
\hline & 1000 & $503 \pm 78$ & $1336 \pm 56$ & $2031 \pm 149$ & $5118 \pm 290$ \\
\hline & 2000 & $762 \pm 34$ & $1429 \pm 78$ & $2534 \pm 316$ & $5619 \pm 335$ \\
\hline & 3000 & $758 \pm 97$ & $1751 \pm 73$ & $2529 \pm 229$ & $6809 \pm 302$ \\
\hline \multirow[t]{4}{*}{$6 \mathrm{~g} \mathrm{NPKhill}^{-1}$} & 0 & $237 \pm 13$ & $753 \pm 33$ & $1068 \pm 126$ & $3729 \pm 110$ \\
\hline & 1000 & $456 \pm 58$ & $1230 \pm 80$ & $1953 \pm 481$ & $4438 \pm 294$ \\
\hline & 2000 & $511 \pm 54$ & $1354 \pm 98$ & $1973 \pm 382$ & $5091 \pm 335$ \\
\hline & 3000 & $784 \pm 92$ & $1443 \pm 55$ & $2926 \pm 493$ & $5020 \pm 346$ \\
\hline \multicolumn{6}{|l|}{ Manure placement mode } \\
\hline Broadcasting & & $527 \pm 41$ & $1202 \pm 108$ & $1864 \pm 60$ & $4472 \pm 149$ \\
\hline Hill placement & & $564 \pm 56$ & $1341 \pm 193$ & $2300 \pm 73$ & $5475 \pm 279$ \\
\hline
\end{tabular}

\pm Standard error.

Table 3

Summary of analysis of variance on grain yields and total dry matter.

\begin{tabular}{|c|c|c|c|}
\hline \multirow[t]{2}{*}{ Source of variation } & \multicolumn{3}{|c|}{ F pr. } \\
\hline & d.f. & Grain yield & Total dry matter \\
\hline Block stratum & 2 & & \\
\hline Fertilizer micro-dosing option & 1 & $<.001$ & $<.001$ \\
\hline Manure rate & 3 & $<.001$ & $<.001$ \\
\hline Manure placement mode & 1 & 0.002 & $<.001$ \\
\hline Year & 1 & $<.001$ & $<.001$ \\
\hline $\begin{array}{l}\text { Fertilizer micro-dosing } \\
\text { option } \times \text { manure rate }\end{array}$ & 3 & 0.709 & 0.759 \\
\hline $\begin{array}{l}\text { Fertilizer micro-dosing } \\
\text { option } \times \text { manure placement } \\
\text { mode }\end{array}$ & 1 & 0.796 & 0.066 \\
\hline $\begin{array}{l}\text { Manure rate } \times \text { manure } \\
\text { placement }\end{array}$ & 3 & 0.285 & 0.006 \\
\hline $\begin{array}{l}\text { Fertilizer micro-dosing } \\
\text { option } \times \text { year }\end{array}$ & 1 & 0.313 & 0.009 \\
\hline Manure rate $\times$ year & 3 & $<.001$ & 0.156 \\
\hline Manure placement $\times$ year & 1 & 0.064 & 0.021 \\
\hline $\begin{array}{l}\text { Fertilizer micro-dosing } \\
\text { option } \times \text { maure } \\
\text { rate } \times \text { manure placement }\end{array}$ & 3 & 0.753 & 0.417 \\
\hline $\begin{array}{l}\text { Fertilizer micro-dosing } \\
\quad \text { option } \times \text { manure rate } \times \text { year }\end{array}$ & 3 & 0.015 & 0.001 \\
\hline $\begin{array}{l}\text { Fertilizer micro-dosing } \\
\text { option } \times \text { manure } \\
\text { placement } \times \text { year }\end{array}$ & 1 & 0.98 & 0.421 \\
\hline $\begin{array}{l}\text { Manure rate } \times \text { manure } \\
\text { placement } \times \text { year }\end{array}$ & 3 & 0.316 & 0.574 \\
\hline $\begin{array}{l}\text { Fertilizer micro-dosing } \\
\text { option } \times \text { manure } \\
\text { rate } \times \text { manure } \\
\text { placement } \times \text { year }\end{array}$ & 3 & 0.421 & 0.474 \\
\hline Residual & 62 & & \\
\hline $\mathrm{CV}(\%)$ & & 24.6 & 26.0 \\
\hline
\end{tabular}

Table 5

Summary of analysis of variance on water use efficiencies (WUE).

\begin{tabular}{|c|c|c|c|}
\hline \multirow[t]{2}{*}{ Source of variation } & \multicolumn{3}{|c|}{ F pr. } \\
\hline & d.f. & WUE in grain & WUE in total dry matter \\
\hline Block stratum & 2 & & \\
\hline $\begin{array}{l}\text { Fertilizer micro-dosing } \\
\text { option }\end{array}$ & 1 & 0.194 & 0.376 \\
\hline Manure rate & 3 & $<.001$ & $<.001$ \\
\hline Manure placement mode & 1 & 0.072 & $<.001$ \\
\hline Year & 1 & $<.001$ & $<.001$ \\
\hline $\begin{array}{l}\text { Fertilizer micro-dosing } \\
\text { option } \times \text { manure rate }\end{array}$ & 3 & 0.754 & 0.754 \\
\hline $\begin{array}{l}\text { Fertilizer micro-dosing } \\
\text { option } \times \text { manure } \\
\text { placement mode }\end{array}$ & 1 & 0.48 & 0.106 \\
\hline $\begin{array}{l}\text { Manure rate } \times \text { manure } \\
\text { placement }\end{array}$ & 3 & 0.753 & 0.117 \\
\hline $\begin{array}{l}\text { Fertilizer micro-dosing } \\
\text { option } \times \text { year }\end{array}$ & 1 & 0.77 & 0.327 \\
\hline Manure rate $\times$ year & 3 & 0.765 & 0.66 \\
\hline Manure placement $\times$ year & 1 & 0.203 & 0.1 \\
\hline $\begin{array}{l}\text { Fertilizer micro-dosing } \\
\text { option } \times \text { maure } \\
\text { rate } \times \text { manure placement }\end{array}$ & 3 & 0.901 & 0.78 \\
\hline $\begin{array}{l}\text { Fertilizer micro-dosing } \\
\text { option } \times \text { manure } \\
\text { rate } \times \text { year }\end{array}$ & 3 & 0.677 & 0.254 \\
\hline $\begin{array}{l}\text { Fertilizer micro-dosing } \\
\text { option } \times \text { manure } \\
\text { placement } \times \text { year }\end{array}$ & 1 & 0.475 & 0.197 \\
\hline $\begin{array}{l}\text { Manure rate } \times \text { manure } \\
\text { placement } \times \text { year }\end{array}$ & 3 & 0.829 & 0.696 \\
\hline $\begin{array}{l}\text { Fertilizer micro-dosing } \\
\text { option } \times \text { manure } \\
\text { rate } \times \text { manure } \\
\text { placement } \times \text { year }\end{array}$ & 3 & 0.615 & 0.218 \\
\hline Residual & 62 & & \\
\hline $\mathrm{CV}(\%)$ & & 27 & 28.3 \\
\hline
\end{tabular}

Table 4

Effect of treatments on grain and total dry matter (TDM) water use efficiencies (WUE).

\begin{tabular}{|c|c|c|c|c|c|}
\hline \multirow[t]{2}{*}{ Fertilizer micro-dosing option } & \multirow[t]{2}{*}{ Manure rate $\left(\mathrm{kg} \mathrm{ha}^{-1}\right)$} & \multicolumn{2}{|c|}{ WUE grain $\left(\mathrm{kg} \mathrm{mm}^{-1}\right)$} & \multicolumn{2}{|c|}{ WUE TDM $\left(\mathrm{kg} \mathrm{mm}^{-1}\right)$} \\
\hline & & 2013 & 2014 & 2013 & 2014 \\
\hline \multirow[t]{4}{*}{$2 \mathrm{~g} \mathrm{DAPhill}^{-1}$} & 0 & $0.9 \pm 0.1$ & $2.0 \pm 0.1$ & $4.9 \pm 0.3$ & $7.8 \pm 0.3$ \\
\hline & 1000 & $1.7 \pm 0.4$ & $2.8 \pm 0.3$ & $6.5 \pm 1.0$ & $11.6 \pm 1.9$ \\
\hline & 2000 & $2.8 \pm 0.7$ & $3.3 \pm 0.7$ & $9.0 \pm 1.3$ & $13.5 \pm 3.4$ \\
\hline & 3000 & $2.3 \pm 0.4$ & $3.5 \pm 0.3$ & $8.3 \pm 1.0$ & $13.8 \pm 2.5$ \\
\hline \multirow[t]{4}{*}{6 g NPKhill-1 } & 0 & $0.7 \pm 0.1$ & $1.7 \pm 0.2$ & $4.1 \pm 0.9$ & $8.7 \pm 0.6$ \\
\hline & 1000 & $1.3 \pm 0.4$ & $2.7 \pm 0.3$ & $5.7 \pm 1.3$ & $10.5 \pm 1.7$ \\
\hline & 2000 & $2.0 \pm 0.6$ & $2.9 \pm 0.2$ & $7.9 \pm 2.2$ & $11.4 \pm 0.4$ \\
\hline & 3000 & $2.8 \pm 0.4$ & $3.0 \pm 0.2$ & $11.2 \pm 1.4$ & $11.1 \pm 0.9$ \\
\hline \multicolumn{6}{|l|}{ Manure placement } \\
\hline Broadcasting & & $1.8 \pm 0.1$ & $2.4 \pm 0.4$ & $6.4 \pm 0.4$ & $9.1 \pm 0.5$ \\
\hline Hill placement & & $1.9 \pm 0.3$ & $3.1 \pm 0.2$ & $8.0 \pm 1.1$ & $13.0 \pm 1$ \\
\hline
\end{tabular}

\pm Standard error. 


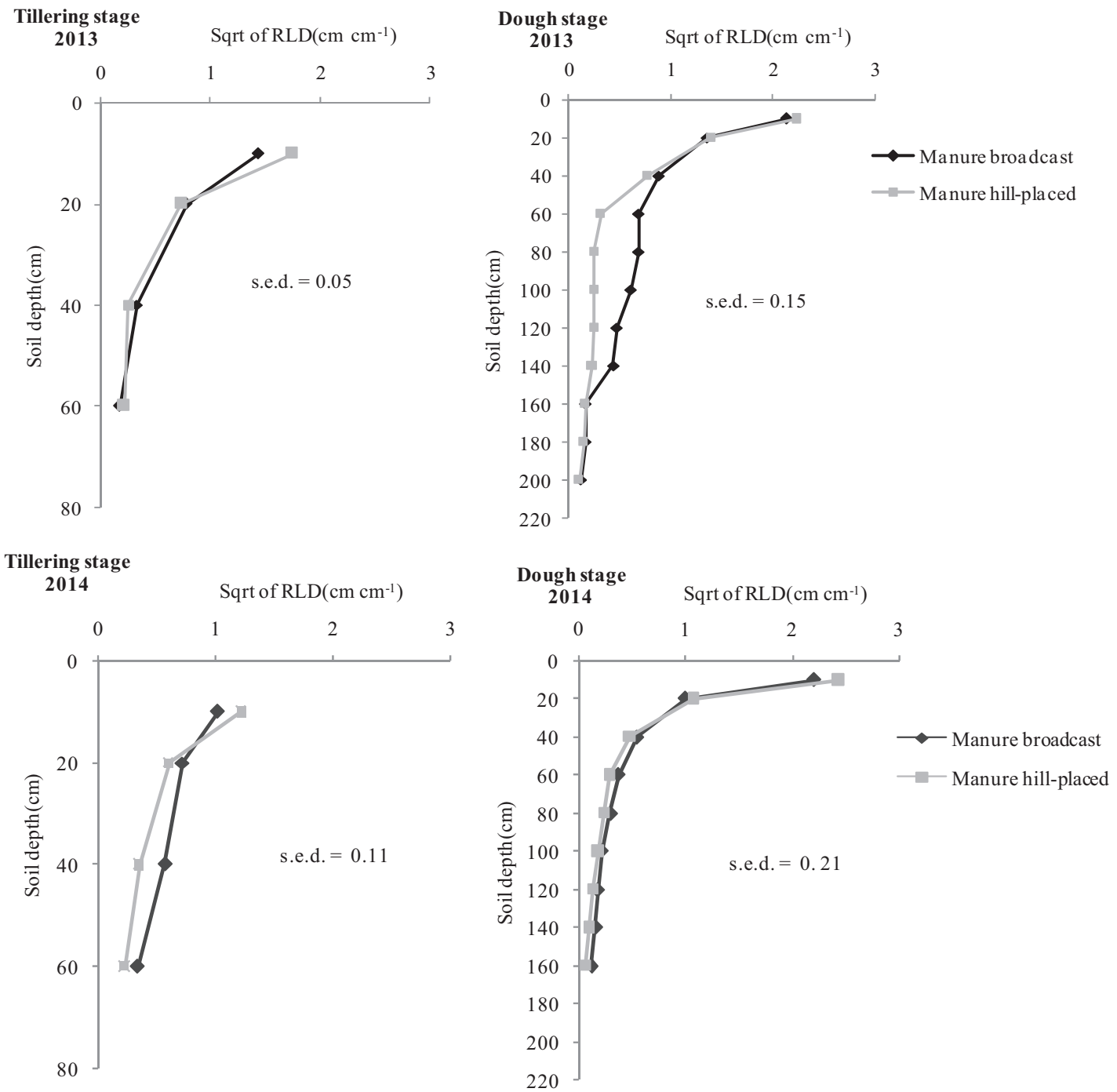

Fig. 2. Effect manure placement on vertical root length density of millet at tillering and dough stages.

\subsection{Effect of treatments on water use efficiency}

Water use efficiencies in grain yield and in total dry matter production are presented in Table 4 and the summary of the analysis of variance is shown in Table 5. Water use efficiency (WUE) in grain yield was relatively very low with fertilizer micro-dosing treatments alone. There was an additive effect of manure and fertilizer micro-dosing on grain yield water use efficiency. WUE in grain yield was markedly increased on average by $68 \%, 129 \%$ and $144 \%$ respectively when $1000 \mathrm{kgha}^{-1}, 2000 \mathrm{~kg} \mathrm{ha}^{-1}$ and $3000 \mathrm{~kg} \mathrm{ha}^{-1}$ were added to fertilizer micro-dosing. The method of manure placement improved the grain water use efficiency; WUE in grain yield was increased on average by $18 \%$ with manure hill placement compared with broadcasting of manure. Similarly, the total dry matter WUE was significantly $(P<0.001)$ improved with manure application. WUE in total dry matter was significantly $(P<0.001)$ increased (on average by $35 \%$ ) with manure hill placement as compared to broadcasting.

\subsection{Effect of treatments on root length density}

The effect of manure placement on vertical root length density (RLD) is shown in Fig. 2. The millet RLD was mostly concentrated in soil layer of $0-20 \mathrm{~cm}$ from tillering to dough stage and dropped drastically in deeper soil layers. The RLD tended to be higher in the topsoil with manure hill placement compared with broadcast; but in the deeper soil layer roots became significantly $(P<0.001)$ denser with broadcasting of manure (Table 6). This increase of RLD in subsoil with broadcasting of manure was particularly important at dough stage in 2013 when the crop experienced rainwater shortage. However, the root distribution in the lateral direction was markedly higher with manure hill placement in all the soil depths compared to manure broadcast (Fig. 3). At the early millet growth stage (tillering), the total lateral RLD was increased by $66 \%$ and $42 \%$ in manure hill placement respectively at $25 \mathrm{~cm}$ and $50 \mathrm{~cm}$ from the hill centre compared with manure broadcast. Similarly, at the dough stage, manure hill placement exhibited greater root distribution pattern in topsoil and deeper soil layers compared with manure broadcast.

\section{Discussion}

Lack of reliable rainfall often obscures the positive response of a crop to a soil fertility management strategy aimed at increasing crop productivity in the Sahelian agroecological of Niger (Bationo et al., 1990; Eyshi Rezaei et al., 2014). The mean grain yield response to fertilizer and manure applications recorded in 2013 were relatively low and were attributed to the low and irregular distribution 
Table 6

Probability values of root length density with respect to different treatments.

\begin{tabular}{|c|c|c|c|c|c|}
\hline & \multicolumn{2}{|c|}{ Tillering stage } & \multicolumn{3}{|c|}{ Dough stage } \\
\hline & $0-20 \mathrm{~cm}$ & $40-100 \mathrm{~cm}$ & $0-20 \mathrm{~cm}$ & $40-100 \mathrm{~cm}$ & $120-200 \mathrm{~cm}$ \\
\hline $\begin{array}{l}\text { Fertilizer } \\
\text { micro-dosing } \\
\text { option }\end{array}$ & NS & NS & NS & NS & NS \\
\hline Manure rate & 0.042 & $<.001$ & $<.001$ & 0.009 & ns \\
\hline Manure placement & NS & 0.025 & 0.02 & 0.036 & NS \\
\hline $\begin{array}{l}\text { Fertilizer } \\
\quad \text { micro-dosing } \\
\text { option } \times \text { manure } \\
\text { rate }\end{array}$ & NS & $<.001$ & NS & 0.007 & NS \\
\hline $\begin{array}{l}\text { Fertilizer } \\
\text { micro-dosing } \\
\text { option } \times \text { manure } \\
\text { placement }\end{array}$ & NS & NS & NS & NS & NS \\
\hline $\begin{array}{l}\text { Manure } \\
\text { rate } \times \text { manure } \\
\text { placement }\end{array}$ & NS & 0.019 & NS & 0.018 & NS \\
\hline $\begin{array}{l}\text { Fertilizer } \\
\quad \text { micro-dosing } \\
\text { option } \times \text { manure } \\
\text { rate } \times \text { manure } \\
\text { placement }\end{array}$ & NS & 0.01 & NS & NS & NS \\
\hline
\end{tabular}

NS = Not significant.

of rainwater during the reproductive stage (Fig. 1). Although it is adapted to dry conditions, millet is sensitive to water shortage especially when this occurs during the flowering stage as was the case in the current study. The low millet grain yield observed in 2013 is rather similar to those reported earlier for the Sahel (Bieler et al., 1993; Graef and Haigis, 2001; Rockström and de Rouw, 1997; Sivakumar and Salaam, 1999; Winkel et al., 1997). Yet, millet responded positively to the nutrient management treatments imposed. Manure application improved millet yield and total dry matter production significantly as compared to the no-manure treatments (Table 2). There was a significant increase in millet yield and total dry matter production when manure was added to the fertilizer micro-dosing (Table 3).

The positive effect of manure on millet yields can be attributed not only to the supply of additional nutrients such as $\mathrm{Ca}$ and $\mathrm{Mg}$ (Bayu et al., 2005; Zingore et al., 2008) which are lacking in sufficient quantity in this experimental sandy soil (Table 1). But this positive effect can also be explained by the low level of organic matter content which limits soil water and nutrient retention in this extremely sandy soil (Table 1). Liu et al. (2013) demonstrated that applications of fertilizer and manure not only accelerated the improvement of soil fertility but also maintained soil water balance, and significantly improved crops yields in the short term. The current results show once more the need for improving soil organic matter in order to enhance millet productivity in low input rainfed farming systems.

The results of the present study confirmed also the earlier reports that showed the positive response of the crop to $\mathrm{N}$ fertilizer in the soil rich in organic matter while the application of the same level of fertilizer in the soil poor in organic matter led to no significant crop response (Zingore et al., 2008). The method of manure application improved millet yields markedly. The hill placement of manure performed better in improving millet grain yield and
$25 \mathrm{~cm}$ from the hill center

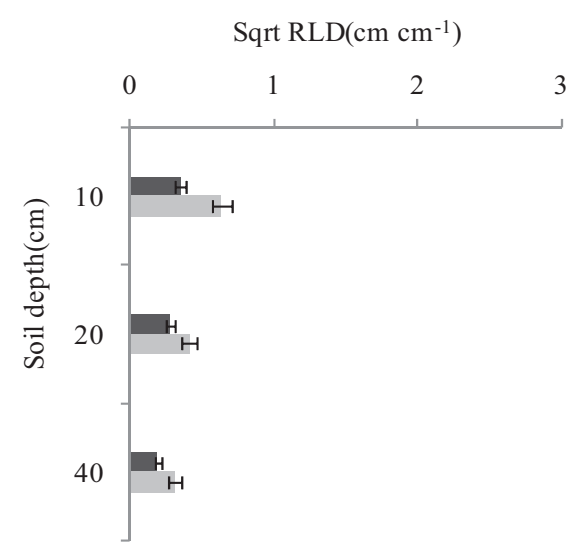

$50 \mathrm{~cm}$ from the hill center

Tillering stage

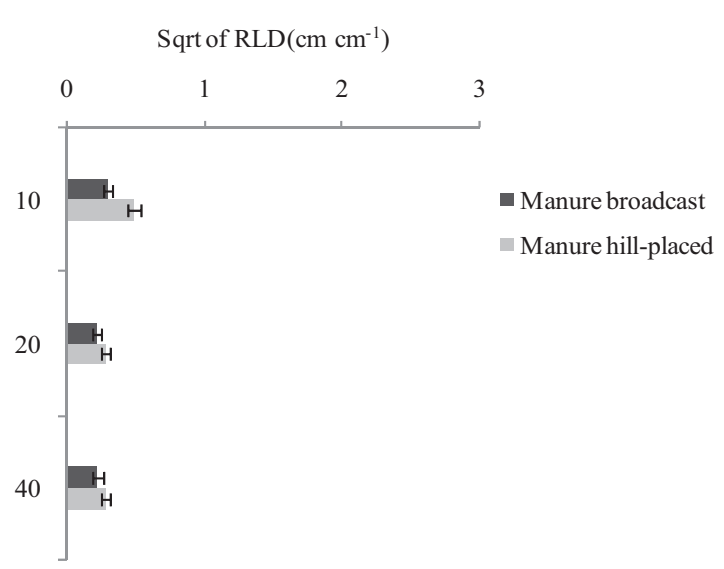

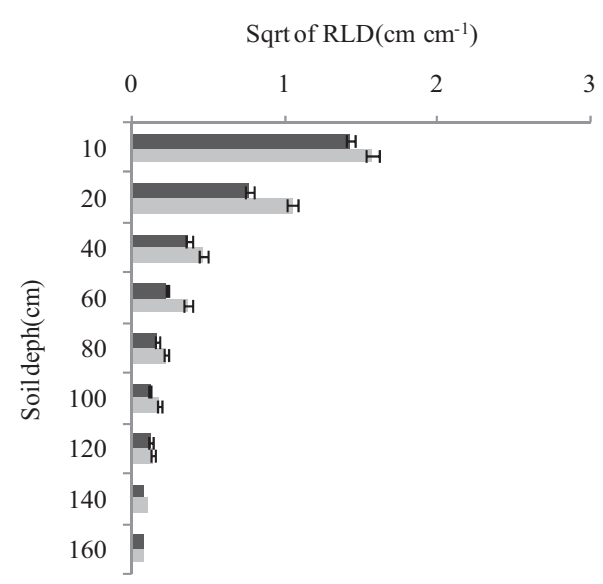

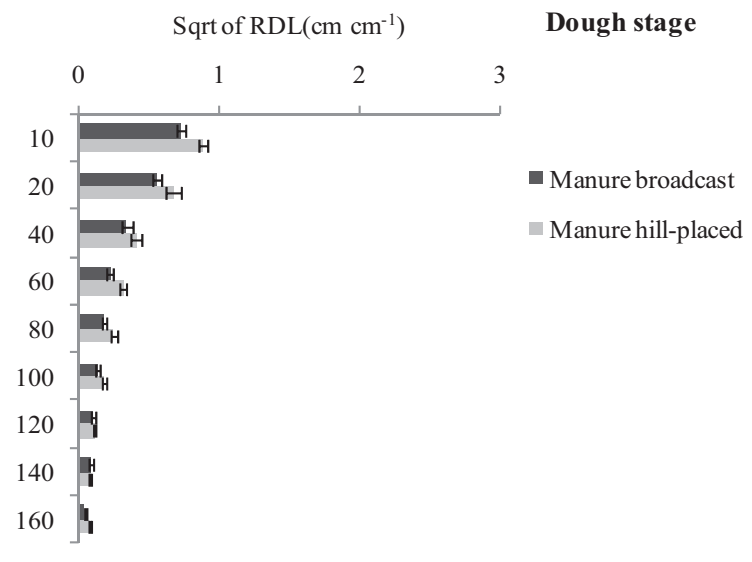

Dough stage

Fig. 3. Effect of manure placement method on lateral root length density at tillering and dough stage in 2014 . 
dry matter than broadcasting, irrespective of the fertilizer microdosing option (Table 3). It is possible that the positive effect of hill placement of manure could have resulted from a better scavenging of the limited amount of nutrients by the roots due to early roots proliferation favoured by hill placement of manure (Figs. 2 and 3). The concentration of manure in the vicinity of crop rooting system, such as was the case in hill application of manure, led to the creation of a "micro-climate" around the plant root system which resulted in the rapid early root growth leading to better use of nutrients and rainwater. Smit et al. (2013) argue that enhancing early root growth could stimulate uptake of soil nutrients such as phosphorus because of high capacity of young roots in improving nutrients uptake capacity.

Increase in grain and biomass yields due to the combined application of fertilizer micro-dosing and manure was accompanied by an increase in the water use efficiency (WUE) (Table 4). Viets (1962) explained that since the evapotranspiration is little affected by the management, as was the case in the current study (data not presented), any factor that increases yield will increase WUE. These results are consistent with the earlier studies which reported an increment of millet water use efficiency in response to soil fertility management options in the Sahelian zone due to increase in biomass production (Akponikpé et al., 2008; Manyame, 2006; Payne, 1997; Yamoah et al., 2002). The results of the present study are also in agreement with the findings of Wang et al. (2013) for maize. The results obtained in the current study indicate that the water use efficiency can be improved through an efficient use of the limited resources available for the smallholder farmers in the Sahel.

There was marked increase in vertical root length density (RLD) values from tillering to dough stage in the topsoil $(0-20 \mathrm{~cm})$ ranging from 2.7 to $5.7 \mathrm{~cm} \mathrm{~cm}^{-3}$ and from 3.4 to $6.5 \mathrm{~cm} \mathrm{~cm}^{-3}$ respectively, for manure broadcast and hill placement (Fig. 2). These values were in close agreement with those reported by Hafner et al. (1993) and Ibrahim et al. (2014). The vertical RLD tended to be higher in the topsoil $(0-20 \mathrm{~cm})$ with manure hill placement. The root length increase influenced by the hill placement of manure can be attributed to roots behaviour tending to be more profuse in root zones where nutrients are mostly concentrated (Hodge, 2004). The greater RLD obtained with manure hill placement in the topsoil indicates a strategy adopted by millet and many other crops to invest in roots where the return is highest (Hodge, 2009). Roots tended to penetrate into deeper soil layers probably to scavenge for water in the case of manure broadcasting in 2013 when the crop experienced a long dry spell during the reproductive phase (Fig. 1). Higher root growth was observed by Hafner et al. (1993) when the rainfall was unfavourable; and by Yamauchi et al. (1996) who showed that there is concentration of roots in the deeper soil layers under drought condition. A high root length density in deeper soil profile is important for the crop because it can make use of water in the subsoil to cope with the dry spells and also utilize nutrient leached in the deeper soil layer (Brück et al., 2003; Wiesler and Horst, 1997).

The results of the current study show that millet production can be improved further by combining the fertilizer micro-dosing technology with the placement of manure. Based on the results of this study, the hill-placement of $2000 \mathrm{~kg} \mathrm{ha}^{-1}$ of manure and $20 \mathrm{~kg} \mathrm{ha}^{-1}$ of DAP appeared to be the most effective combination for improving millet yield, nutrient and water use efficiencies in the Sahelian millet-based systems. However, hill application of manure requires further labour investment for digging the holes which can be a constraint on the adoption of this technology. Consideration of the economic benefits will surely guide farmers' decision to the adoption of this technology. There is therefore a need to test this technology further, together with farmers to enable a more effective economic analysis of the technology.

\section{Acknowledgement}

We thank Alliance for Green Revolution in Africa (AGRA) for the Ph.D. grant to the first author, and Prof. Oene Oenema for reviewing the draft version of this manuscript.

\section{References}

Abdoulaye, T., Sanders, J.H., 2005. Stages and determinants of fertilizer use in semiarid African agriculture: the Niger experience. Agric. Econ. 32, 167-179.

Akponikpé, P.B.I., Michels, K., Bielders, C.L., 2008. Integrated nutrient management of pearl millet in the Sahel combining cattle manure, crop residues and mineral fertilizer. Exp. Agric. 44, 453-472.

Aune, J.B., Bationo, A., 2008. Agricultural intensification in the Sahel-the ladder approach. Agric. Syst. 98, 119-125

Bationo, A., Buerkert, A., Sedogo, M., Christianson, B., Mokwunye, A., 1995. A critical review of crop residue use as soil amendment in the West African semi-arid tropics. Livestock and sustainable nutrient cycling in mixed farming systems of sub-Saharan Africa. 2, 305-322.

Bationo, A., Christianson, C.B., Baethgen, W.E., 1990. Plant density and nitrogen fertilizer effects on pearl millet production in Niger. Agron. J. 82, 290-295.

Bationo, A., Christianson, C.B., Klaij, M.C., 1993. The effect of crop residue and fertilizer use on pearl millet yields in Niger. Fertil. Res. 34, 251-258.

Bationo, A., Mokwunye, U., Vlek, P.L., Koala, S., Shapiro, B.I., 2003. Soil fertility management for sustainable land use in the West African Sudano-Sahelian zone. In: Gichuri, M.P., Bationo, A., Bekunda, M.A., Goma, H.C., Mafongoya, P.L., Mugendi, D.N., Murwuira, H.K., Nandwa, S.M., Nyathi, P., Swift, M.J. (Eds.), Soil Fertility Management in Africa: A Regional Perspective. Academy Science Publishers (ASP), pp. 253-292.

Bayu, W., Rethman, N.F.G., Hammes, P.S., 2005. The role of animal manure in sustainable soil fertility management in Sub-Saharan Africa: a review. J. Sustain. Agric. 25, 113-136.

Bieler, P., Fussell, L.K., Bidinger, F.R., 1993. Grain growth of Pennisetum glaucum (L.) R. Br. under well-watered and drought-stressed conditions. Field Crops Res. 31, 41-54.

Brück, H., Sattelmacher, B., Payne, W., 2003. Varietal differences in shoot and rooting parameters of pearl millet on sandy soils in Niger. Plant Soil 251, 175-185.

Buerkert, A., Hiernaux, P., 1998. Nutrients in the West African Sudano-Sahelian zone: losses, transfers and role of external inputs. J. Plant Nutr. Soil Sci. 161, 365-383.

De Ridder, N., Van Keulen, H., 1990. Some aspects of the role of organic matter in sustainable intensified arable farming systems in the West-African semi-aridtropics (SAT). Fertil. Res. 26, 299-310.

Eyshi Rezaei, E., Gaiser, T., Siebert, S., Sultan, B., Ewert, F., 2014. Combined impacts of climate and nutrient fertilization on yields of pearl millet in Niger. Eur. J. Agron. $55,77-88$.

Graef, F., Haigis, J., 2001. Spatial and temporal rainfall variability in the Sahel and its effects on farmers' management strategies. J. Arid Environ. 48, 221-231.

Hafner, H., George, E., Bationo, A., Marschner, H., 1993. Effect of crop residues on root growth and phosphorus acquisition of pearl millet in an acid sandy soil in Niger. Plant Soil 150, 117-127.

Hayashi, K., Abdoulaye, T., Gerard, B., Bationo, A., 2008. Evaluation of application timing in fertilizer micro-dosing technology on millet production in Niger. West Afr. Nutr. Cycl. Agroecosyst. 80, 257-265.

Hodge, A., 2004. The plastic plant: root responses to heterogeneous supplies of nutrients. New Phytol. 162, 9-24.

Hodge, A., 2009. Root decisions. Plant Cell Environ. 32, 628-640.

Houba, V., Van der Lee, J., Novozamsky, I., 1995. Soil Analysis Procedures; Other Procedures (Soil And Plant Analysis, Part 5B). Department of Soil Science and Plant Nutrition, Wageningen Agricultural University, Wageningen, The Netherlands, pp. 217.

Ibrahim, A., Pasternak, D., Fatondji, D., 2014. Impact of depth of placement of mineral fertilizer micro-dosing on growth, yield and partial nutrient balance in pearl millet cropping system in the Sahel. J. Agric. Sci., 1-10, http://dx.doi.org/10.1017/ S0021859614001075 (FirstView).

ICRISAT, 2009. Fertilizer microdosing-boosting production in unproductive lands. 〈http://www.icrisat.org/impacts/impact-stories/icrisat-is-fertilizermicrodosing $\rangle$ (accessed 14.02.14.).

Klaij, M., Vachaud, G., 1992. Seasonal water balance of a sandy soil in Niger cropped with pearl millet, based on profile moisture measurements. Agric. Water Manag. 21, 313-330.

Liu, C.-A., Li, F.-R., Zhou, L.-M., Zhang, R.-H., Lin, S.-L., Wang, L.-J., Siddique, K.H., Li, F.-M., 2013. Effect of organic manure and fertilizer on soil water and crop yields in newly-built terraces with loess soils in a semi-arid environment. Agric. Water Manag. 117, 123-132.

Manyame, C., 2006. On-Farm Yield And Water Use Response Of Pearl Millet To Different Management Practices in Niger. Texas A\&M University, TX, USA, pp. 138 (Ph.D dissertation).

McIntire, J., Powell, J., Fernández-Rivera, S., Williams, T., 1993. African semi-arid tropical agriculture cannot grow without external inputs. In: Proceedings of the International Conference on Livestock and Sustainable Nutrient Cycling in Mixed Farming Systems of Sub-Saharan Africa, Addis Ababa (Ethiopia), 22-26 Nov, 1993

Payne, W.A., 1997. Managing yield and water use of pearl millet in the Sahel. Agron. J. 89, 481-490. 
Rockström, J., de Rouw, A., 1997. Water, nutrients and slope position in on-farm pearl millet cultivation in the Sahel. Plant Soil 195, 311-327.

Schlecht, E., Buerkert, A., Tielkes, E., Bationo, A., 2006. A critical analysis of challenges and opportunities for soil fertility restoration in Sudano-Sahelian West Africa. Nutr. Cycl. Agroecosyst. 76, 109-136.

Sivakumar, M.V.K., Maidoukia, A., Stern, R.D., 1993. Agroclimatology of West Africa: Niger. International Crops Research Institute for the Semi-Arid Tropics, and Direction de la météorologie nationale du Niger, Patancheru, A.P., India, Niamey, pp. 116 (Information Bulletin no 5, 502 324).

Sivakumar, M.V.K., Salaam, S.A., 1999. Effect of year and fertilizer on water-use efficiency of pearl millet (Pennisetum glaucum) in Niger. J. Agric. Sci. 132, 139-148.

Smit, A.L., Blom-Zandstra, M., van der Werf, A., Bindraban, P.S., 2013. Enhancing Early Root Growth To Exploit Indigenous Soil P And Fertilizer P. Virtual Fertilizer Research Center, Washington, D.C (VFRC Report 2013/4, 36pp).

Stoorvogel, J., Smaling, E., 1990. Assessment of Soil Nutrient Depletion in SubSaharan Africa: 1983-2000. Winand Staring Centre, Wageningen.

Tabo, R., Bationo, A., Amadou, B., Marchal, D., Lompo, F., Gandah, M., Hassane, O., Diallo, M.K., Ndjeunga, J., Fatondji, D., Gerard, B., Sogodogo, D., Taonda, J.B.S. Sako, K., Boubacar, S., Abdou, A., Koala, S., 2011. Fertilizer microdosing and "warrantage" or inventory credit system to improve food security and farmers' income in West Africa. In: Bationo, A., Waswa, B., Okeyo, J.M., Maina, F. Kihara, J.M. (Eds.), Innovations as Key to the Green Revolution in Africa. Springer, Netherlands, pp. 113-121.

Tabo, R., Bationo, A., Gerard, B., Ndjeunga, J., Marchal, D., Amadou, B., Annou, M.G., Sogodogo, D., Taonda, J.-B.S., Hassane, O., 2007. Improving cereal productivity and farmers' income using a strategic application of fertilizers in West Africa. In: Advances in Integrated Soil Fertility Management In Sub-Saharan Africa: Challenges And Opportunities. Springer, The Netherlands, pp. 201-208.

Tennant, D., 1975. A test of a modified line intersect method of estimating root length. J. Ecol. 63, 995-1001.
Trust, L.A., 2007. Genstat. Lawes Agricultural Trust (Rothamsted Experimental Station), Rothamsted, UK

van Reeuwijk, L.P., 1993. Procedures for soil analysis. Technical paper No 9, Fourth edition edited by the International Soil Reference and Information Center(ISRIC).

Viets, F.G., 1962. Fertilizers and the efficient use of water. Adv. Agron. 14, 223-264.

Walkley, A., Black, I.A., 1934. An examination of the Degtjareff method for determining soil organic matter, and a proposed modification of the chromic acid titration method. Soil Sci. 37, 29-38.

Wang, X., Dai, K., Wang, Y., Zhang, X., Zhao, Q., Wu, X., Cai, D., Hoogmoed, W., Oenema, O., 2010. Nutrient management adaptation for dryland maize yields and water use efficiency to long-term rainfall variability in China. Agric. Water Manag. 97, $1344-1350$

Wang, X., Jia, Z.K., Liang, L., Kang, S., 2013. Effect of manure management on the temporal variations of dryland soil moisture and water use efficiency of maize. J. Agric. Sci. Technol. 15, 1293-1304.

Wiesler, F., Horst, W.J., 1997. Root growth and nitrate utilization of maize cultivars under field conditions. Plant Soil 163, 267-277.

Winkel, T., Renno, J.-F., Payne, W., 1997. Effect of the timing of water deficit on growth, phenology and yield of pearl millet (Pennisetum glaucum (L.) R. Br.) grown in Sahelian conditions. J. Exp. Bot. 48, 1001-1009.

Yamauchi, A., Pardales, J.JJr., Kono, Y., 1996. Root System Structure And Its Relation To Stress Tolerance. Dynamics of Roots And Nitrogen In Cropping Systems Of The Semi-Arid Tropics. Japan International Research Center for Agricultural Sciences, Tokyo, pp. 211-233.

Yamoah, C.F., Bationo, A., Shapiro, B., Koala, S., 2002. Trend and stability analyses of millet yields treated with fertilizer and crop residues in the Sahel. Field Crops Res. 75, 53-62.

Zingore, S., Delve, R.J., Nyamangara, J., Giller, K.E., 2008. Multiple benefits of manure: the key to maintenance of soil fertility and restoration of depleted sandy soils on African smallholder farms. Nutr. Cycl. Agroecosyst. 80, 267-282. 